\title{
Occurrence of common scab and black scurf in selected potato cultivars grown under organic and conventional crop production systems
}

\author{
Występowanie parcha zwykłego i ospowatości bulw \\ w wybranych odmianach ziemniaka uprawianego \\ w systemie ekologicznym i konwencjonalnym
}

\author{
Krystyna Zarzyńska*, Milena Pietraszko, Piotr Barbaś
}

\begin{abstract}
Summary
The research was carried out in 2014-2017 at the Institute of Plant Breeding and Acclimatization, in the Jadwisin Branch, in the center of Poland. The subject of the research were potato tubers grown in an organic and conventional system, assessed for symptoms of common scab and black scurf. Seven cultivars belonging to two groups of earliness were examined. It was found that the share of tubers with common scab symptoms depended on the cultivar, the conditions prevailing in the research years and the production system. A higher share of infected tubers was found on tubers from the organic system, although statistically significant differences were observed in one year of research. The degree of tuber infestation depended on the variety and production system. Significant differentiation in terms of the share of tubers infected with Rhizoctonia solani and the degree of tuber infestation was observed between the cultivars and the production system. The cultivars Bogatka and Oberon were the least susceptible to infection with $R$. solani and bacteria of the genus Streptomyces in the organic system.
\end{abstract}

Key words: potato, organic system, conventional system, common scab, black scurf, cultivar

\section{Streszczenie}

Badania przeprowadzono w latach 2014-2017 w Instytucie Hodowli i Aklimatyzacji Roślin w Oddziale Jadwisin, w centralnej Polsce. Przedmiotem badań były bulwy ziemniaka uprawianego w ekologicznym i konwencjonalnym systemie uprawy, oceniane pod kątem objawów parcha zwykłego i ospowatości bulw. Zbadano siedem odmian należących do dwóch grup wczesności. Stwierdzono, że udział bulw z objawami parcha zwykłego zależał od odmiany, warunków panujących w latach badań oraz systemu produkcji. Wyższy udział bulw porażonych stwierdzono w odmianach ziemniaka pochodzących z systemu ekologicznego, chociaż statystycznie istotne różnice obserwowano w jednym roku badań. Stopień porażenia bulw zależał od odmiany i systemu produkcji. Istotne zróżnicowanie pod względem udziału bulw porażonych Rhizoctonia solani i stopniem porażenia bulw obserwowano pomiędzy odmianami i systemem produkcji. Najmniejszą podatnością na infekcje $R$. solani i bakteriami z rodzaju Streptomyces w systemie ekologicznym wyróżniły się odmiany Bogatka i Oberon.

Słowa kluczowe: ziemniak, system ekologiczny, system konwencjonalny, parch, ospowatość, odmiana

Instytut Hodowli i Aklimatyzacji Roślin - Państwowy Instytut Badawczy

Szaniawskiego 15, Jadwisin, 05-140 Serock

*corresponding author: k.zarzynska@ihar.edu.pl

ORCID: 0000-0002-8747-2785 


\section{Wstęp / Introduction}

Po wstąpieniu Polski do Unii Europejskiej rozwój rolnictwa ekologicznego w Polsce stał się bardzo dynamiczny. Największą liczbę gospodarstw ekologicznych i największą powierzchnię upraw odnotowano w roku 2013. W ostatnich latach obserwuje się wprawdzie niewielkie spadki, ale nadal jesteśmy w czołówce krajów europejskich i zajmujemy siódme miejsce pod względem liczby gospodarstw i dziewiąte pod względem powierzchni uprawy. W strukturze upraw ekologicznych największy udział stanowią łąki i pastwiska oraz rośliny paszowe (GIJHARS 2019). Ziemniak, pomimo że nadal jest jedną z podstawowych roślin uprawnych w Polsce, w uprawach ekologicznych stanowi niewielki procent. Powierzchnia uprawy tego gatunku w systemie ekologicznym wynosi tylko około 1500 ha (GIJHARS 2019). Ziemniak jest rośliną trudną w uprawie ekologicznej ze względu na duże zagrożenie ze strony agrofagów, a szczególnie stonki ziemniaczanej i organizmu grzybopodobnego Phytophthora infestans wywołującego zarazę ziemniaka.

Jednym z problemów w produkcji ziemniaków w ogóle, a w produkcji ekologicznej w szczególności są choroby skórki bulw. W warunkach Polski podstawowe znaczenie mają: parch zwykły, parch srebrzysty i ospowatość bulw ziemniaka. Są one szczególnie istotne w przypadku sadzeniaków oraz ziemniaków jadalnych i przeznaczonych dla przemysłu spożywczego. Najczęściej występującą chorobą skórki jest parch zwykły, wywoływany przez bytujące w glebie bakterie z rodzaju Streptomyces. Spośród 17 gatunków tego rodzaju największe znaczenie mają: Streptomyces scabies (Thaxter), Streptomyces acidiscabies oraz Streptomyces turgidiscabies (Lambert i wsp. 2006). Do porażenia bulw dochodzi w glebie w początkowym okresie ich rozwoju (Hide i Lapwood 1992). Źródłem porażenia mogą być sadzeniaki, a rozwojowi chorób sprzyjają niektóre zabiegi agrotechniczne oraz warunki środowiska (Szutkowska i Lutomirska 2002; Wróbel 2003; Hiltunen i wsp. 2005; Lambert i wsp. 2006; Wanner 2006).

Rozwojowi parcha zwykłego sprzyja głównie stosowanie nierozłożonego, słomiastego obornika, ale czynnikiem decydującym o silnej infekcji są przede wszystkim niedobory wody w okresie wytwarzania bulw. Bakteria najlepiej rozwija się w czasie wiązania bulw, kiedy jest sucho i temperatura powietrza sięga $30^{\circ} \mathrm{C}$ (Lutomirska 2002, 2008; Gawińska-Urbanowicz 2007). Źródłem saprotroficznych bakterii powodujących parcha zwykłego jest zanieczyszczona bakteriami gleba, chore bulwy i resztki po wcześniej uprawianych ziemniakach.

Sprawcą rizoktoniozy jest grzyb Thanatephorus cucumeris - forma doskonała, którego formą niedoskonałą jest Rhizoctonia solani. Patogen może rozwijać się na bulwach i roślinach przez cały okres wegetacji. Objawy powodowane przez $R$. solani, zaliczane do chorób skórki, to występujące na powierzchni bulw czarne skupiska grzybni przetrwalni- kowej - sklerocja, nazwane ospowatością bulw ziemniaka. Choroba prowadzi do ograniczenia ilości oraz jakości plonu. Grzyb $R$. solani najlepiej rozwija się w glebie o dużej ilości substancji organicznej pochodzącej z obornika lub ewentualnie przedplonów koniczyny. Osadzaniu się skrelocjów na bulwach sprzyjają okresy długotrwałego optymalnego nawilgotnienia (Radtke i wsp. 2000; Lutomirska i Jankowska 2013). Najnowsze badania dotyczące porażenia $R$. solani i bakteriami z rodzaju Streptomyces dotyczą zrozumienia związków między występowaniem patogenów a mikrobiomem gleby. Okazuje się, że istnieją tu ścisłe zależności (Ciancio i wsp. 2016; Liu i wsp. 2018; Wencong i wsp. 2019). Należy zwrócić uwagę, że na jakość plonu ziemniaka duży wpływ mają właściwości genetyczne danej odmiany oraz ich współdziałanie z czynnikami przyrodniczymi i agrotechnicznymi. Jednym z czynników agrotechnicznych jest system produkcji, w którym uprawiane są ziemniaki.

Celem badań była ocena odmian ziemniaka oraz ocena wpływu systemu produkcji i warunków panujących w okresie wegetacji na porażenie bulw przez grzyb $R$. solani i bakterie z rodzaju Streptomyces.

\section{Materiały i metody / Materials and methods}

Badania przeprowadzone były w latach 2014-2017 w Instytucie Hodowli i Aklimatyzacji Roślin, w Oddziale Jadwisin, w Polsce centralnej. Ziemniak uprawiany był na glebie płowej o składzie granulometrycznym piasku gliniastego lekkiego w dwóch systemach produkcji: ekologicznym i konwencjonalnym. Płodozmian stosowany w systemie ekologicznym: ziemniak - jęczmień jary - mieszanka peluszki z grochem pastewnym i żytem jarym - mieszanka łubinu żółtego i owsa - żyto z wsiewką seradeli. Płodozmian stosowany w systemie konwencjonalnym: ziemniak - pszenica jara - pszenica ozima - łubin. Oba systemy produkcji różniły się nawożeniem, sposobem zwalczania chwastów oraz metodami ochrony przed chorobami i szkodnikami (tab. 1). Badaniami objęto siedem odmian ziemniaka $\mathrm{z}$ dwóch grup wczesności, tj. wczesnych i średnio wczesnych: 3 wczesne - Cyprian, Ignacy, Michalina oraz cztery średnio wczesne - Bogatka, Jurata, Malaga i Oberon. Przy doborze odmian uwzględniano ich odporność na Phytophtora infestans. Wszystkie odmiany były sadzone w tym samym czasie, tj. około 23 kwietnia w rozstawie $75,0 \times 33,3 \mathrm{~cm}$, po 60 roślin każdej odmiany w każdym z trzech powtórzeń. Charakterystykę wszystkich odmian podano w tabeli 3 .

Po zbiorze plonu dokonano oceny porażenia bulw przez grzyb $R$. solani i bakterie z rodzaju Streptomyces. Próba stanowiła około $6 \mathrm{~kg}$ ziemniaków wybranych losowo z każdego poletka. Porażenie tymi patogenami oceniano po 2-3 tygodniach od zbioru bulw przy użyciu dwóch parametrów: stopnia porażenia bulw i procentowego udziału 
Tabela 1. Agrotechnika stosowana w systemie ekologicznym i konwencjonalnym Table 1. Agronomic inputs in organic and conventional systems

\begin{tabular}{|c|c|c|}
\hline $\begin{array}{c}\text { Stosowane zabiegi } \\
\text { Crop production practice }\end{array}$ & $\begin{array}{l}\text { System ekologiczny } \\
\text { Organic system }\end{array}$ & $\begin{array}{l}\text { System konwencjonalny } \\
\text { Conventional system }\end{array}$ \\
\hline $\begin{array}{l}\text { Nawożenie } \\
\text { Fertilization }\end{array}$ & $\begin{array}{l}\text { obornik } 28 \mathrm{t} / \mathrm{ha}+\text { gorczyca jako poplon } \\
\text { manure } 28 \mathrm{t} / \mathrm{ha}+\text { mustard as a catch crop }\end{array}$ & $\begin{array}{c}4-5 \mathrm{t} \text { przyoranej słomy żytniej } \\
+1 \mathrm{~kg} \text { azotu mineralnego na } 100 \mathrm{~kg} \text { słomy } \\
4-5 \text { t plowed rye straw } \\
+1 \mathrm{~kg} \text { mineral nitrogen per } 100 \mathrm{~kg} \text { straw } \\
\text { N } 100 \mathrm{~kg} / \mathrm{ha} \\
\text { P } 53 \mathrm{~kg} / \mathrm{ha} \\
\mathrm{K} 150 \mathrm{~kg} / \mathrm{ha}\end{array}$ \\
\hline $\begin{array}{l}\text { Zwalczanie chwastów } \\
\text { Weed control }\end{array}$ & $\begin{array}{l}\text { tylko mechaniczne } \\
\text { only mechanical tillage }\end{array}$ & $\begin{array}{c}\text { mechaniczne }+ \text { herbicydy } \\
\text { mechanical tillage }+ \text { herbicides } \\
\text { Linurex } 1,81 / \mathrm{ha} \\
\text { Titus } 60 \mathrm{~g} / \mathrm{ha}+\text { Trend } 0,5 \mathrm{l} / \mathrm{ha}\end{array}$ \\
\hline $\begin{array}{l}\text { Ochrona przed stonką ziemniaczaną } \\
\text { Colorado potato beetle control }\end{array}$ & $\begin{array}{c}\text { biologiczny insektycyd } \\
\text { biological insecticide } \\
\text { Spin Tor } 240 \mathrm{SC} \\
0,151 / \text { ha (spinosad) } \\
2 \text { razy w sezonie }-2 \text { times per season }\end{array}$ & $\begin{array}{c}\text { chemiczne insektycydy } \\
\text { chemical insecticides } \\
\text { Actara } 60 \mathrm{~g} / \mathrm{ha} \\
2 \text { razy w sezonie }-2 \text { times per season } \\
\text { Apacz } 40 \mathrm{~g} / \mathrm{ha}\end{array}$ \\
\hline $\begin{array}{l}\text { Ochrona przed zarazą ziemniaka } \\
\text { Late blight control }\end{array}$ & $\begin{array}{l}\text { fungicydy miedziowe } \\
\text { copper fungicides } \\
\text { Miedzian } 5031 / \text { ha } \\
2 \text { razy w sezonie } \\
2 \text { times per season }\end{array}$ & $\begin{array}{l}\text { chemiczne fungicydy } \\
\text { chemical fungicides } \\
\text { Ridomil } 21 / \mathrm{ha} \\
\text { Revus } 0,61 / \mathrm{ha} \\
\text { Ranman } 0,21 / \mathrm{ha} \\
\text { Altima } 0,41 / \mathrm{ha}\end{array}$ \\
\hline
\end{tabular}

Tabela 2. Suma miesięcznych opadów (O) i średnia miesięcznych temperatur (T) podczas okresu wegetacji w latach 2014-2016 dla Jadwisina

Table 2. Total monthly rainfall $(\mathrm{O})$ and mean monthly temperatures $(\mathrm{T})$ during the vegetative growth period in the years 2014-2016 for Jadwisin

\begin{tabular}{|c|c|c|c|c|c|c|c|c|c|c|c|c|}
\hline \multirow{2}{*}{$\begin{array}{l}\text { Rok } \\
\text { Year }\end{array}$} & \multicolumn{2}{|c|}{ IV } & \multicolumn{2}{|c|}{ V } & \multicolumn{2}{|c|}{ VI } & \multicolumn{2}{|c|}{ VII } & \multicolumn{2}{|c|}{ VIII } & \multicolumn{2}{|c|}{ IX } \\
\hline & $\begin{array}{c}\mathrm{O} \\
{[\mathrm{mm}]}\end{array}$ & $\begin{array}{c}\mathrm{T} \\
{\left[{ }^{\circ} \mathrm{C}\right]}\end{array}$ & $\begin{array}{c}\mathrm{O} \\
{[\mathrm{mm}]}\end{array}$ & $\begin{array}{c}\mathrm{T} \\
{\left[{ }^{\circ} \mathrm{C}\right]}\end{array}$ & $\begin{array}{c}\mathrm{O} \\
{[\mathrm{mm}]}\end{array}$ & $\begin{array}{c}\mathrm{T} \\
{\left[{ }^{\circ} \mathrm{C}\right]}\end{array}$ & $\begin{array}{c}\mathrm{O} \\
{[\mathrm{mm}]}\end{array}$ & $\begin{array}{c}\mathrm{T} \\
{\left[{ }^{\circ} \mathrm{C}\right]}\end{array}$ & $\begin{array}{c}\mathrm{O} \\
{[\mathrm{mm}]}\end{array}$ & $\begin{array}{c}\mathrm{T} \\
{\left[{ }^{\circ} \mathrm{C}\right]}\end{array}$ & $\begin{array}{c}\mathrm{O} \\
{[\mathrm{mm}]}\end{array}$ & $\begin{array}{c}\mathrm{T} \\
{\left[{ }^{\circ} \mathrm{C}\right]}\end{array}$ \\
\hline 2014 & 61,1 & 10,3 & 41,3 & 14,1 & 69,8 & 15,8 & 23,5 & 21,5 & 79,2 & 18,2 & 11,9 & 14,8 \\
\hline 2015 & 27,8 & 8,3 & 39,5 & 12,9 & 15,4 & 17,5 & 62,3 & 19,6 & 8,6 & 22,5 & 36,6 & 15,1 \\
\hline 2016 & 92,2 & 15,3 & 85,4 & 18,7 & 103,6 & 19,6 & 61,4 & 18,4 & 9,5 & 15,7 & 92,2 & 15,3 \\
\hline
\end{tabular}

Tabela 3. Charakterystyka odmian ziemniaka uprawianych w systemie ekologicznym i konwencjonalnym, badanych w latach 2014-2016

Table 3. Characteristics of potato cultivars evaluated in organic and conventional production systems during 2014-2016

\begin{tabular}{l|c|c|c}
\hline \multicolumn{1}{c|}{ Odmiana - Cultivar } & Wczesność - Earliness & $\begin{array}{c}\text { Odporność na } \\
\text { Resistance to } \\
\text { Phytophthora infestans } *\end{array}$ & $\begin{array}{c}\text { Odporność na } \\
\text { Resistance to } \\
\text { Streptomyces scabies }\end{array}$ \\
\hline Cyprian & wczesna - early & 5 & 5,5 \\
\hline Ignacy & wczesna - early & 3,5 & 7 \\
\hline Michalina & wczesna - early & 3 & 7,6 \\
\hline Bogatka & średnio wczesna - mid-early & 3,5 & 6,5 \\
\hline Jurata & średnio wczesna - mid-early & 4 & 6 \\
\hline Malaga & średnio wczesna - mid-early & 3,5 & 5 \\
\hline Oberon & średnio wczesna - mid-early & 3,5 & 5,7 \\
\hline
\end{tabular}

*9 - pełna odporność - full resistance, 1 - brak odporności - no resistance 
bulw porażonych w próbie. Ocenie poddawano każdą bulwę w próbie określając stopień jej porażenia według 9-stopniowej skali COBORU, w której 9 - oznacza bulwę zdrową o skórce wolnej od zmian chorobowych, natomiast 1 - bulwę, na skórce której stwierdzono objawy parcha przynajmniej na 50\% powierzchni, a w przypadku ospowatości przynajmniej na 25\% (Roztropowicz 1999). Jako wynik obserwacji każdej próby zapisywano ich masę w określonym stopniu. Następnie obliczano wskaźnik (indeks) porażenia i procent bulw z objawami. Uzyskane dane poddano analizom statystycznym za pomocą programu STATISTICA. Przeprowadzono 3-czynnikową analizę wariancji. Czynnikami różnicującymi daną cechę były: odmiana, system produkcji, lata oraz ich współdziałanie. Istotność różnic pomiędzy średnimi testowano testem Tukeya.

\section{Wyniki i dyskusja / Results and discussion}

\section{Istotność zróżnicowania badanych czynników}

W przypadku porażenia bulw bakteriami z rodzaju Streptomyces istotne zróżnicowanie dotyczące procentowego udziału bulw porażonych odnosiło się do wszystkich badanych czynników, tj. systemu produkcji, odmiany, lat, a także interakcji odmiany z systemem produkcji. Stopień porażenia próby zależał od odmiany i systemu produkcji. Lata badań nie miały istotnego wpływu na tę cechę.

W przypadku porażenia $R$. solani istotne różnice dotyczące procentowego udziału bulw porażonych dotyczyły odmian i systemu produkcji. Nie stwierdzono istotnego wpływu na tę cechę lat badań. Stwierdzono jednak występowanie interakcji systemu produkcji i odmiany. Stopień porażenia próby z objawami ospowatości zależał w istotny sposób od systemu produkcji i odmiany.

\section{Porażenie bulw bakteriami z rodzaju Streptomyces w zależności od systemu produkcji, odmiany i lat badań}

\section{Udzial bulw porażonych}

Średnio dla wszystkich odmian udział bulw z objawami parcha zwykłego wyrażony w procentach wynosił dla systemu ekologicznego $35,1 \%$, a dla systemu konwencjonalnego 16,5\%. Wystąpiło duże zróżnicowanie odmianowe. Największe porażenie odnotowano w obu systemach produkcji u odmian Michalina i Ignacy. W systemie konwencjonalnym brak porażenia odnotowano u odmiany Bogatka, a u odmian Malaga i Oberon porażenie wynosiło poniżej $10 \%$ (tab. 4).

Warunki pogodowe panujące $\mathrm{w}$ latach badań również istotnie różnicowały udział bulw z objawami parcha. Najniższy udział bulw porażonych wystąpił w obu systemach produkcji w roku 2014. W roku 2015 porażenie bulw było na zbliżonym poziomie i najwyższe $\mathrm{w}$ obu systemach produkcji. Największe zróżnicowanie wystąpiło w roku 2016, w którym to w systemie konwencjonalnym tylko $10 \%$ bulw uległo porażeniu, a w systemie ekologicznym aż 55\% (tab. 4).

\section{Stopień porażenia próby}

Stopień (indeks) porażenia próby bakteriami z rodzaju Streptomyces zależał w sposób istotny od systemu produkcji i odmiany. W systemie ekologicznym porażenie próby było wyższe niż w systemie konwencjonalnym i wynosiło odpowiednio 7,3 i 8,2 w skali 9-stopniowej, gdzie 9 - oznacza brak porażenia. Średnio najmniej porażoną była odmiana Bogatka, a najbardziej - odmiana Michalina (tab. 5).

Tabela 4. Udział bulw z objawami parcha zwykłego w zależności od systemu produkcji, odmiany i lat badań [\%]

Table 4. Tuber infection by common scab depending on crop production system, cultivar and years of research [\%]

\begin{tabular}{l|c|c|c}
\hline \multirow{2}{*}{ Odmiana - Cultivar } & \multicolumn{2}{|c|}{ System produkcji - Crop production system } & \multirow{2}{*}{ Średnio - Mean } \\
\cline { 2 - 4 } & ekologiczny - organic & konwencjonalny - conventional & $13,0 \mathrm{~A}$ \\
\hline Bogatka & $26,1 \mathrm{bc}$ & $0 \mathrm{a}$ & $17,1 \mathrm{~A}$ \\
\hline Oberon & $24,5 \mathrm{bc}$ & $9,6 \mathrm{ab}$ & $21,8 \mathrm{AB}$ \\
\hline Jurata & $23,2 \mathrm{bc}$ & $20,3 \mathrm{bc}$ & $22,5 \mathrm{AB}$ \\
\hline Malaga & $39,1 \mathrm{~cd}$ & $5,8 \mathrm{a}$ & $24,1 \mathrm{AB}$ \\
\hline Cyprian & $26,3 \mathrm{bc}$ & $21,8 \mathrm{bc}$ & $37,0 \mathrm{BC}$ \\
\hline Ignacy & $46,3 \mathrm{~cd}$ & $27,7 \mathrm{bc}$ & $44,9 \mathrm{CD}$ \\
\hline Michalina & $59,9 \mathrm{~d}$ & $30,0 \mathrm{c}$ & 25,8 \\
\hline Średnio-Mean & $35,1 \mathrm{~B}$ & $16,5 \mathrm{~A}$ & $10,0 \mathrm{~A}$ \\
\hline 2014 & & $7,8 \mathrm{a}$ & $37,4 \mathrm{BC}$ \\
\hline 2015 & $37,3 \mathrm{ab}$ & $31,0 \mathrm{bc}$ & $32,8 \mathrm{BC}$ \\
\hline
\end{tabular}

a, b, c, A, B, C - dane oznaczone tą samą literą nie różnią się statystycznie - data marked with the same letter do not differ statistically 
Tabela 5. Stopień porażenia próby bakteriami z rodzaju Streptomyces w zależności od systemu produkcji i odmiany

Table 5. Grade of tuber infection by Streptomyces depending on crop production system and cultivar

\begin{tabular}{l|c|c|c}
\hline \multirow{2}{*}{ Odmiana - Cultivar } & \multicolumn{2}{|c|}{ System produkcji - Production system } & \multirow{2}{*}{ Średnio - Mean } \\
\cline { 2 - 4 } & ekologiczny - organic & konwencjonalny - conventional & $6,9 \mathrm{~A}$ \\
\hline Michalina & $6,2 \mathrm{a}$ & $7,6 \mathrm{bc}$ & $7,3 \mathrm{AB}$ \\
\hline Ignacy & $6,9 \mathrm{ab}$ & $7,7 \mathrm{bc}$ & $7,8 \mathrm{~B}$ \\
\hline Cyprian & $7,7 \mathrm{bc}$ & $7,9 \mathrm{~cd}$ & $7,9 \mathrm{~B}$ \\
\hline Malaga & $7,0 \mathrm{~b}$ & $8,8 \mathrm{de}$ & $8,0 \mathrm{BC}$ \\
\hline Jurata & $8,0 \mathrm{~d}$ & $8,0 \mathrm{~d}$ & $8,2 \mathrm{BC}$ \\
\hline Oberon & $7,8 \mathrm{bc}$ & $8,6 \mathrm{~d}$ & $8,4 \mathrm{CD}$ \\
\hline Bogatka & $7,8 \mathrm{bc}$ & $9,0 \mathrm{de}$ & 7,8 \\
\hline Średnio - Mean & $7,3 \mathrm{~A}$ & $8,2 \mathrm{~B}$ & \\
\hline
\end{tabular}

*9 - najmniejszy stopień porażenia - the smallest grade of infection, 1 - największy stopień porażenia (skala odwrócona) - the biggest grade of infection a, b, c, A, B, C - dane oznaczone tą samą literą nie różnią się statystycznie - data marked with the same letter do not differ statistically

Zarówno plon ziemniaka, jak i jakość bulw zależą od wielu czynników. Główne obejmują warunki glebowe, klimatyczne, odmianowe i agronomiczne. Wśród czynników agronomicznych ważną rolę odgrywa system produkcji. W Polsce, podobnie jak na świecie, podstawowym systemem produkcji jest system konwencjonalny, ale obok niego coraz częściej spotykany jest system ekologiczny i integrowany. Od ekologicznie uprawianych ziemniaków oczekujemy ogólnie lepszego smaku i lepszej wartości odżywczej kosztem nieco gorszego wyglądu (Zarzyńska i Goliszewski 2006). Stosowane w tym systemie nawozy organiczne, płodozmian bogaty w rośliny wieloletnie i nawozy zielone przyczyniają się do wzrostu infekcji niektórymi patogenami wywołującymi choroby, takie jak parch czy rizoktonioza (Gransedt i Kjellenberg 1997; Stein-Bachingerxy i Werner 1997; Frinckh i wsp. 2006). Szczególnie dużą wadą są bulwy z objawami parcha. W przeprowadzonych badaniach stwierdzono zróżnicowanie porażenia bulw patogenem wywołującym parcha w zależności od odmiany, jak i od warunków atmosferycznych panujących w latach badań. Są to, jak wiadomo czynniki decydujące o stopniu porażenia (Jankowska i wsp. 2015). W przedstawionych badaniach najmniejsze porażenie bulw wystąpiło w 2014 roku, kiedy to rozkład opadów i temperatura panująca w okresie wiązania bulw (czerwiec) były najmniej korzystne do rozwoju parcha (tab. 2). Najlepsze warunki dla rozwoju parcha wystąpiły w roku 2015, w którym to w początkowym okresie tuberyzacji (czerwiec) opady wynosiły tylko 15,4 mm i w obu systemach produkcji porażenie bulw ziemniaka bakteriami z rodzaju Streptomyces było wysokie. Największe zróżnicowanie między systemami wystąpiło w roku 2016. Wpływ warunków atmosferycznych w okresie wegetacji na występowanie parcha zwykłego potwierdzają także inni: Rudkiewicz i Zakrzewska (1987), Głuska i Nowacki (2001), Wanner (2006) oraz Lutomirska (2008).
Autorzy tych prac stwierdzają bowiem, że największe porażenie bulw ma miejsce wtedy, kiedy w okresie ich wiązania występuje wysoka temperatura i niski poziom opadów. Nie bez znaczenia pozostaje również stosowana agrotechnika (Szutkowska i Lutomirska 2002; Wróbel 2003). Autorzy ci podają, że stosowanie obornika i wykonywanie częstych uprawek sprzyja rozwojowi parcha. W badaniach Zarzeckiej i wsp. (2009) udział bulw z objawami parcha, oraz średni stopień porażenia próby były istotnie determinowane przez sposoby odchwaszczania. Herbicydy i ich mieszaniny zastosowane do odchwaszczania plantacji ograniczały porażenie bulw wywołane przez $S$. scabies, co przyczyniło się do poprawy jakości plonu ziemniaka. Jak wiadomo, w uprawie ekologicznej stosowanie wszelkich chemicznych środków produkcji jest zabronione, stąd większe możliwości dla rozwoju choroby.

Jak już wspomniano dużą rolę w występowaniu parcha odgrywa czynnik genetyczny. Dlatego, tym większego znaczenia nabiera dobór odmian o podwyższonej odporności na te choroby (Stein-Bachingerxy i Werner 1997; Zarzyńska i Goliszewski 2006). Nawet najbardziej odporne i wysoko plonujące odmiany nie zyskają uznania w produkcji ekologicznej, jeśli nie będą charakteryzowały się wysoką jakością bulw. W zaprezentowanych badaniach najlepiej pod tym względem wypadły odmiany Bogatka i Oberon. Najbardziej podatnymi odmianami na parcha były odmiany Michalina i Ignacy.

\section{Porażenie bulw ospowatością w zależności od systemu produkcji, odmiany i lat badań}

\section{Udzial bulw porażonych}

Średni procentowy udział bulw porażonych $R$. solani był istotnie wyższy u odmian uprawianych w systemie konwencjonalnym niż w ekologicznym i wynosił odpowiednio $18,2 \%$ i 5,6\%. Średnio dla systemów produkcji najwyższą 
odpornością na porażenie charakteryzowały się odmiany Oberon i Bogatka, a najniższą odmiana Cyprian (tab. 6).

\section{Stopień porażenia próby}

Średnio, odmiany były porażone słabiej w uprawie systemem ekologicznym. Różnice pomiędzy systemem produkcji czy pomiędzy odmianami były wprawdzie statystycznie istotne, ale zakres zmienności tej cechy był wąski i wynosił 0,5 stopnia dla systemów produkcji (średnie 8,2 i 8,7) i 1,4 dla odmian w danym systemie produkcji (od 7,6 do 9,0). Najsłabiej była porażona odmiana Malaga w systemie ekologicznym, a najsilniej odmiana Cyprian - w systemie konwencjonalnym (tab. 7).

Ospowatość bulw jest jednym z objawów porażenia przez grzyb $R$. solani. Znaczenie choroby wzrosło w ostatnich latach w związku ze wzrostem spożycia ziemniaków mytych i paczkowanych w małe woreczki. Większość danych literaturowych (Stein-Bachingerxy i Werner 1997; Frinckh i wsp. 2006; Ciancio i wsp. 2016; Liu i wsp. 2018) donosi, że w systemie ekologicznym porażenie jest większe niż w systemie konwencjonalnym, ponieważ warunki do rozwoju choroby, tj. np. duża ilość substancji organicznej w glebie są bardziej sprzyjające. W przeprowadzonych badaniach taka prawidłowość nie wystąpiła. Zarówno udział bulw porażonych, jak i stopień porażenia próby były niższe w systemie ekologicznym. Badania Lenca (2006) wykazały, zanieczyszczenia bulw sklerocjami $R$. solani na tym samym poziomie w obu systemach uprawy, natomiast w wykonanych badaniach udział bulw porażonych, jak i stopień porażenia próby były niższe w systemie ekologicznym. Mogło to być związane z rozwojem korzystnej mikrobioty. Jak już wspomniano, warunki uprawy w systemie ekologicznym mogą sprzyjać nasileniu parcha i rizoktoniozy, ale z drugiej strony, system ten sprzyja rozwojowi gatunków antagonistycznych (Lenc 2006) oraz ich aktywności (Liu i wsp. 2018; Wencong i wsp. 2019).

Warunki pogodowe panujące w latach badań nie wpłynęły w sposób istotny na udział bulw z objawami ospowatości. Większa wilgotność gleby w czasie dojrzewania bulw według Sadowskiego i wsp. (2003) sprzyja rozwojowi sklerocjów $R$. solani. W przedstawionych badaniach jedynie

Tabela 6. Udział bulw z objawami ospowatości w zależności od systemu produkcji i odmiany [\%]

Table 6. Share of tuber with black scurf symptoms depending on crop production system and cultivar [\%]

\begin{tabular}{l|c|c|c}
\hline \multirow{2}{*}{ Odmiana - Cultivar } & \multicolumn{2}{|c|}{ System produkcji-Crop production system } & \multirow{2}{*}{ Średnia - Mean } \\
\cline { 2 - 4 } & ekologiczny - organic & konwencjonalny - conventional & $4,2 \mathrm{~A}$ \\
\hline Oberon & $4,1 \mathrm{ab}$ & $4,3 \mathrm{ab}$ & $6,4 \mathrm{~A}$ \\
\hline Bogatka & $5,2 \mathrm{ab}$ & $7,6 \mathrm{ab}$ & $11,0 \mathrm{AB}$ \\
\hline Malaga & $1,6 \mathrm{a}$ & $20,4 \mathrm{abc}$ & $11,6 \mathrm{AB}$ \\
\hline Ignacy & $13,5 \mathrm{abc}$ & $9,6 \mathrm{ab}$ & $15,0 \mathrm{~B}$ \\
\hline Jurata & $2,6 \mathrm{a}$ & $27,3 \mathrm{bc}$ & $15,2 \mathrm{~B}$ \\
\hline Michalina & $7,2 \mathrm{ab}$ & $23,2 \mathrm{abc}$ & $19,8 \mathrm{C}$ \\
\hline Cyprian & $4,8 \mathrm{a}$ & $34,7 \mathrm{ab}$ & 8,4 \\
\hline Średnio-Mean & $5,6 \mathrm{~A}$ & $8,2 \mathrm{~A}$ & \\
\hline
\end{tabular}

a, b, c, A, B, C - dane oznaczone tą samą literą nie różnią się statystycznie - data marked with the same letter do not differ statistically

Tabela 7. Stopień porażenia próby z objawami ospowatości w zależności od systemu produkcji i odmiany

Table 7. Grade of tuber infection by black scurf depending on crop production system and cultivar

\begin{tabular}{l|c|c|c}
\hline \multirow{2}{*}{ Odmiana - Cultivar } & \multicolumn{2}{|c|}{ System produkcji - Crop production system } & \multirow{2}{*}{ Średnia - Mean } \\
\cline { 2 - 4 } & ekologiczny - organic & konwencjonalny - conventional & $8,0 \mathrm{~A}$ \\
\hline Jurata & $8,3 \mathrm{abc}$ & $7,8 \mathrm{ab}$ & $8,2 \mathrm{AB}$ \\
\hline Cyprian & $8,8 \mathrm{bcd}$ & $7,6 \mathrm{a}$ & $8,3 \mathrm{AB}$ \\
\hline Michalina & $8,7 \mathrm{bcd}$ & $7,8 \mathrm{abc}$ & $8,6 \mathrm{BC}$ \\
\hline Malaga & $9,0 \mathrm{~d}$ & $8,1 \mathrm{abcd}$ & $8,8 \mathrm{CD}$ \\
\hline Bogatka & $8,8 \mathrm{bcd}$ & $8,7 \mathrm{bcd}$ & $8,8 \mathrm{CD}$ \\
\hline Oberon & $8,8 \mathrm{~cd}$ & $8,8 \mathrm{~cd}$ & $8,5 \mathrm{BC}$ \\
\hline Ignacy & $8,4 \mathrm{abcd}$ & $8,6 \mathrm{abcd}$ & 8,5 \\
\hline Średnio - Mean & $8,7 \mathrm{~B}$ & $8,2 \mathrm{~A}$ & \\
\hline
\end{tabular}

a, b, c, A, B, C - dane oznaczone tą samą literą nie różnią się statystycznie - data marked with the same letter do not differ statistically 
w roku 2014 opady w sierpniu były wysokie, a w pozostałych latach niskie. Przyczyną braku istotności wpływu warunków pogodowych na porażenie bulw mogło więc być zbyt małe ich zróżnicowanie w kolejnych latach. Podatność odmian na infekcję $R$. solani jest zróżnicowana. W badaniach Lenca (2006) porażenie bulw poszczególnych odmian ziemniaka przez $R$. solani różniło się między latami badań i wahało się od wysokiego do niskiego. Podobne różnice w reakcji na tego patogena zaobserwowali Sadowski i wsp. (2004) oraz Lutomirska i Jankowska (2013). Na znaczenie pogody w okresie pełni rozwoju roślin dla występowania ospowatości bulw wskazują wyniki Lutomirskiej (2002, 2007) oraz Lutomirskiej i Jankowskiej (2013), które większy udział bulw z ospowatością w zbieranym plonie stwierdzały wówczas, gdy sumy opadów w sierpniu, tzn. w fazie pełni rozwoju większości poddanych ocenie odmian, były wyższe od norm wieloletnich. Potwierdzają to również badania Wróbla (2003) oraz Zarzeckiej i wsp. (2009).

\section{Wnioski / Conclusions}

1. Porażenie bulw bakteriami z rodzaju Streptomyces zależało od wszystkich badanych czynników, tj.: systemu produkcji, odmiany i warunków panujących w latach badań. Istotnie wyższe porażenie stwierdzono na bulwach pochodzących z systemu ekologicznego.

2. Na stopień porażenia próby przez bakterie z rodzaju Streptomyces istotny wpływ miał czynnik odmianowy i system produkcji.

3. Porażenie bulw grzybem $R$. solani i stopień porażenia próby zależały w istotny sposób od czynnika odmianowego i sposobu uprawy.

4. Zróżnicowanie porażenia odmian przez oba patogeny wskazuje na możliwość doboru odmian o mniejszej podatności na choroby do uprawy systemem ekologicznym. Spośród siedmiu badanych odmian Bogatka i Oberon wyróżniały się najmniejszą podatnością na porażenie omawianymi patogenami w tym systemie uprawy.

\section{Literatura / References}

Ciancio A., Pieterse C.M.J., Mercado-Blanco J. 2016. Harnessing useful rhizosphere microorganisms for pathogen and pest biocontrol. Frontiers in Microbiology 7: 1620. DOI: 10.3389/fmicb.2016.01620

Frinckh M.R., Schulte-Geldemann E., Bruns C. 2006. Challenges to organic potato farming: disease and nutrient management. Potato Research 49: 27-42. DOI 10.100/s11540-006-9004-3

Gawińska-Urbanowicz H. 2007. Ocena występowania chorób grzybowych i bakteryjnych ziemniaka w warunkach polowych. Biuletyn Instytutu Hodowli i Aklimatyzacji Roślin 243: 191-197.

GIJHARS 2019. Raport o stanie rolnictwa ekologicznego w Polsce w latach 2017-2018.

Głuska A., Nowacki W. 2001. Wpływ opadów i warunków glebowych na porażenie bulw parchem zwykłym (Streptomyces scabies). s. 72-77. W: Konferencja „Ochrona ziemniaka”. Kołobrzeg, 19-21 marca 2001. Instytut Hodowli i Aklimatyzacji Roślin, Oddział Bonin.

Gransedt A., Kjellenberg L. 1997. Long-term field experiment in Sweeden: Effect of organic and inorganic fertilizers on soil fertility and crop quality. s. 79-90. W: Proceedings of an International Conference in Boston, Tufts University, Agricultural Production and Nutrition. Massachusetts, March 19-21, 1997.

Hide G.A., Lapwood D.H. 1992. Disease aspects of potato production. s. 403-437. W: The Potato Crop. World Crop Series (P.M. Harris, red). Springer, Dordrecht. DOI: 10.1007/978-94-011-2340-2_10

Hiltunen L.H., Weckman A., Ylhäinen A., Rita H., Richter H., Valkonen J.P.T. 2005. Responses of potato cultivars to the common scab pathogens, Streptomyces scabies and S. turgidicabies. Annals of Applied Biology 146 (3): 395-403. DOI: 10.1111/j.17447348.2005.040083.x

Jankowska J., Lutomirska B., Pietraszko M. 2015. Występowanie parcha zwykłego na bulwach ziemniaka w zależności od warunków meteorologicznych. Ziemniak Polski 3: 23-29.

Lambert D.H., Reeves A.F., Goth R.W., Grounds G.S., Giggie E.A. 2006. Relative susceptibility of potato varieties to Streptomyces scabies and S. acidiscabies. American Journal of Potato Research 83: 67-70. DOI: 10.1007/BF02869611

Lenc L. 2006. Wpływ podkiełkowywania sadzeniaków na występowanie Rhizoctonia solani Kühn na kiełkach i bulwach sześciu odmian ziemniaka uprawianego w systemie ekologicznym. [Effect of pre-sprouting of potato tubers on occurrence of Rhizoctonia solani Kühn on sprouts and tubers of six organically grown potato cultivars]. Journal of Research and Applications in Agricultural Engineering 51 (2): 104-107.

Liu K., Mc Inroy J.A., Hu C.H., Kloepper J.W. 2018. Mixtures of plant-growth-promoting rhizobacteria enhance biological control of multiple plant diseases and plant-growth promotion in the presence of pathogens. Plant Disease 102 (1): 67-72. DOI: 10.1094/PDIS04-17-0478-RE

Lutomirska B. 2002. Wpływ temperatury gleby i opadów w czasie wegetacji na porażenie bulw ziemniaka ospowatością i parchem zwykłym. [Influence of soil temperature and rainfall during growing period on the infection of potato tubers with black scurf and common scab]. Zeszyty Problemowe Postępów Nauk Rolniczych 481: 491-496.

Lutomirska B. 2007. Wpływ odmiany i czynników meteorologicznych okresu wegetacji na ospowatość bulw ziemniaka. Progress in Plant Protection/Postępy w Ochronie Roślin 47 (2): 173-177.

Lutomirska B. 2008. Wpływ czynników meteorologicznych na porażenie bulw ziemniaka parchem zwykłym. Progress in Plant Protection/ Postępy w Ochronie Roślin 48 (1): 216-220.

Lutomirska B., Jankowska J. 2013. Ospowatość bulw zaawansowanych materiałów hodowlanych ziemniaka. [Black scurf in tubers of the potato advanced breeding material]. Progress in Plant Protection/Postępy w Ochronie Roślin 53 (4): 789-795. DOI: 10.14199/ ppp-2013-026 
Radtke W., Rieckmann W., Brendler F. 2000. Kartoffel: Krankheiten - Schadlinge - Unkräuter. Verlag Th. Mann, Gelsenkirchen Buer, 272 ss. ISBN 978-37-8620-11-37

Roztropowicz S. (red.). 1999. Metodyka obserwacji, pomiarów i pobierania prób w agrotechnicznych doświadczeniach z ziemniakiem. Praca zbiorowa. Instytut Hodowli i Aklimatyzacji Roślin, Oddział Bonin, 50 ss.

Rudkiewicz F., Zakrzewska B. 1987. Wpływ niektórych elementów pogody na porażenie bulw parchem zwykłym i ocena przydatności procentu i stopnia porażenia bulw do określania reakcji odmian na ten patogen. Biuletyn Instytutu Ziemniaka 35: 91-100.

Sadowski C., Klepin J., Baturo A., Lenc L. 2003. Zdrowotność bulw i kiełków ziemniaka uprawianego w systemie ekologicznym i konwencjonalnym. Zeszyty Problemowe Postępów Nauk Rolniczych 486: 95-102.

Sadowski C., Pańka D., Lenc L. 2004. Porównanie zdrowotności bulw i kiełków wybranych odmian ziemniaka uprawianych w systemie ekologicznym. Zeszyty Problemowe Postępów Nauk Rolniczych 500: 373-381.

Stein-Bachingerxy K., Werner W. 1997. Effect of manure on crop yield and quality in an organic agricultural system. Biological Agriculture \& Horticulture 14 (3): 221-235. DOI: 10.1080/01448765.1997.9754812

Szutkowska M., Lutomirska B. 2002. Wpływ środowiska i niektórych zabiegów agrotechnicznych na porażanie się bulw ziemniaka parchem zwykłym. Biuletyn Instytutu Hodowli i Aklimatyzacji Roślin 221: 153-167.

Wanner L.A. 2006. A survey of genetic variation in Streptomyces isolates causing potato common scab in the United States. Phytopathology 96 (12): 1363-1371. DOI: 10.1094/PHYTO-96-1363

Wencong S., Mingcong L., Guangshan W., Renmao T., Cuiping L., Bing W., Rongshan L., Chunyu S., Xiuli C., Bo Z. 2019. The occurrence of potato common scab correlates with the community composition and function of the geocaulosphere soil microbiome. Microbiome 7: 14. DOI: 10.1186/s40168-019-0629-2

Wróbel S. 2003. Porażenie bulw ziemniaka parchem zwykłym i rizoktoniozą w zależności od zabiegów stosowanych w nasiennictwie. Biuletyn Instytutu Hodowli i Aklimatyzacji Roślin 228: 283-289.

Zarzecka K., Gugała M., Rymuza K. 2009. Wpływ metod agrotechnicznych i herbicydów na porażenie przez rizoktoniozę (Rhizoctonia solani) bulw ziemniaka odmiany Wiking. Biuletyn Instytutu Hodowli i Aklimatyzacji Roślin 251: 235-241.

Zarzyńska K., Goliszewski W. 2006. Rola odmiany w ekologicznej produkcji ziemniaka. Journal of Research and Applications in Agricultural Engineering 51 (2): 214-219. 